\title{
EFFECT OF EXTRACTIVES ON WOOD COLOR OF HEAT TREATED Pinus radiata AND Eucalyptus pellita
}

\author{
Antônio José Vinha Zanuncio,^, Amélia Guimarães Carvalho ${ }^{1}$, Milene Teixeira de Souza ${ }^{2}$, \\ Carolina Marangon Jardim ${ }^{1}$, Angélica de Cassia Oliveira Carneiro' ${ }^{1}$, Jorge Luiz Colodette ${ }^{2}$
}

\begin{abstract}
Heat treatment can change wood color without any use of environmentally harmful chemicals, and the efficiency of this process depends on the raw material to be treated. The objective of this study was to evaluate the influence of extractives on the color change of Eucalyptus pellita and Pinus radiata wood during heat treatment. The extractives were extracted in cold water and in dichloromethane as well as totally removed and the wood was treated at $170^{\circ} \mathrm{C}$ and $200^{\circ} \mathrm{C}$ for three hours under atmospheric pressure and in presence of air for evaluating the lightness $\left(\mathrm{L}^{*}\right)$, green-red coordinate $\left(\mathrm{a}^{*}\right)$, blue-yellow coordinate $\left(\mathrm{b}^{*}\right)$, color saturation $(\mathrm{C})$ and tonality angle $(\mathrm{H})$ values. Pinus radiata wood was more resistant to discoloration by heat treatment. The removal of total and cold water-soluble extractives before heat treatment changed the $\mathrm{L}^{*}$ value of Pinus radiata, a* value of Eucalyptus pellita, and b*, C, and $\mathrm{H}$ values of both species. Removal of extractives soluble in dichloromethane did not affect the color of heat treated wood. Thus, understanding the influence of extractives on heat treated wood can allow adapting the raw material to the process for enhancing the applicability of heat treatment for changing wood color.

Keywords: Colorimetry, green-red coordinate, lightness, thermal treatment, wood extractives.
\end{abstract}

\section{INTRODUCTION}

The traditional methods of changing wood color involved use of chemicals, like varnishes and paints, resulting in generation of toluene and xylene (Korkut 2012). In comparison, heat treatment is an environmentally friendly and convenient method for changing the color of wood. This process involves application of heat of $160-230^{\circ} \mathrm{C}$ on the wood to be treated (Kocaefe et al. 2008, Esteves and Pereira 2009, Pétrissans et al. 2014). This temperature range degrades the hemicellulose and extractives (Brito et al. 2008, Zanuncio et al. 2014c). As positive effect, heat treatment reduces hygroscopicity and increases the dimensional stability (Esteves et al. 2013, Palermo et al. 2014, Ratnasingam and Ioras 2012, Bal and Bektaş 2012), as negative effect, it damages the mechanical properties of wood (Garcia et al. 2012, Dundar et al. 2012, Cademartori et al. 2012, Dubey et al. 2012).

The wood extractives influence the color of heat treated wood (Chen et al. 2012), they vary between wood species, part of the tree, and environmental conditions (Alañón et al. 2011, Zanuncio et al. 2013). Other factors such as difference between radial and longitudinal section, species and conditions of treatment also influences the color of the wood heat treated (Picelli et al. 2012, Cademartori et al. 2013, Sun et al. 2013).

\footnotetext{
${ }^{1}$ Departamento de Engenharia Florestal, Universidade Federal de Viçosa, 36570- 000, Viçosa, Brazil.

2 Departamento de Ciências Florestais, Universidade Federal de Lavras, 37200-000, Lavras, Brazil.

^Corresponding author: ajvzanuncio@yahoo.com.br

Received: 14.07.2014 Accepted: 26.07.2015
} 
The CIELAB system (1976) is the most commonly used method to evaluate color of materials. In this system, " $\mathrm{L} *$ " indicates lightness with a scale of 0 to 100 and values increasing from black to white; " $\mathrm{a}$ *" indicates the green-red coordinate with a positive number, indicating the red and negative green colors; " $b$ *" indicates blue-yellow coordinate with a positive number, indicating yellow and the negative blue colors; "color saturation" (C) indicates the purity of the color; and "tonality angle" $(\mathrm{H})$ indicates the dominance of any component in the color.

The effect of extractives on color change during heat treatment of wood is not well known. Thus, the objective of this study was to evaluate the influence of extractives on the color change of $P$. radiata and E. pellita wood during heat treatment.

\section{MATERIAL AND METHODS}

Disks of 10-cm thickness were cut at 1,3 $\mathrm{m}$ above the ground level from three 8-year-old E. pellita trees and from three 14-year-old $P$. radiata trees. The average diameter of the discs were $16,1 \mathrm{~cm}$ and 22,2 cm for E. pellita and $P$. radiata, respectively. The samples were triturated using Willey mill, sieved through 40 - and 60-mesh sieves, and the fraction retained in 60-mesh sieves was conditioned in a climatic chamber at $23 \pm 1{ }^{\circ} \mathrm{C}$ and relative humidity of $50 \pm 2 \%$.

The extractives soluble in dichloromethane were determined according to the American Society for Testing and Materials ASTM D-1108-94 (1994); extractives soluble in cold water according to ASTM D-1110-94 (1994) and the total extractives according to ASTM D-1105-94 (1994). Then, the samples were heat treated at $170^{\circ} \mathrm{C}$ and $200^{\circ} \mathrm{C}$ for three hours in an oven at atmospheric pressure and in the presence of air.

Colorimetric analysis of wood was carried out by using the CM-2500D Konica Minolta spectrophotometer. The colorimetric parameters evaluated included the following: lightness $\left(\mathrm{L}^{*}\right)$, green-red coordinate $\left(\mathrm{a}^{*}\right)$, and blue-yellow coordinate $\left(\mathrm{b}^{*}\right)$ with reference to the CIELAB (1976) color coordinate system.

The color saturation $(\mathrm{C})$ was calculated with the following equation: $\mathrm{C}=\left[\left(\mathrm{a}^{*}\right)^{2}+\left(\mathrm{b}^{*}\right)^{2}\right]^{0,5}$, where: $\mathrm{C}=$ color saturation; $\mathrm{a}^{*}=$ green-red coordinate; $\mathrm{b}^{*}=$ blue-yellow coordinate. The tonality angle $(\mathrm{H})$ was determined according to the following equation: $\mathrm{H}=\operatorname{arctang}\left(\mathrm{b}^{*} / \mathrm{a}^{*}\right)$, where: $\mathrm{H}=$ tonality angle $(\mathrm{H}) ; \mathrm{a}^{*}=$ green-red coordinate; $b^{*}=$ blue-yellow coordinate.

The extraction and heat treatment were carried out with five replicates per treatment. In each sample, the colorimetric analysis was performed three times.

The means were subjected to analysis of variance (ANOVA) and, when established significant differences $(\mathrm{p}<0,05)$; the treatments were compared by Scott-Knott test 0,05 probability level, according to Melo et al. 2015. 


\section{RESULTS AND DISCUSSION}

The extractive content of E. pellita and P. radiata ranged from $1,72 \%$ to $5,91 \%$ and from $1,25 \%$ to $3,58 \%$ for the different extraction types, respectively (Table 1).

Table 1. Extractives content of E. pellita and P. radiata soluble in cold water, dichloromethane and total extractives.

\begin{tabular}{cccc}
\hline Wood & Cold water (\%) & Dichloromethane (\%) & Total extractives (\%) \\
\hline E. pellita & $3,55 \mathrm{~b}$ & $1,72 \mathrm{c}$ & $5,91 \mathrm{a}$ \\
P. radiata & $1,25 \mathrm{c}$ & $1,88 \mathrm{~b}$ & $3,58 \mathrm{a}$ \\
\hline
\end{tabular}

Means followed by the same letter per line do not differ by the Scott Knott test at $5 \%$ probability.

The proportion of extractives soluble in cold water in E. pellita was higher than in dichloromethane, which represents the pattern for most hardwoods (Moya and Tenorio 2013, Kilic and Niemz 2012), mainly of Eucalyptus species (Morais and Pereira 2012, Zanuncio et al. 2014b). On the other hand, the proportion of extractives soluble in dichloromethane in P. radiata was higher than that in E. pellita. In general, conifers have a higher proportion of extractives soluble in dichloromethane than hardwoods, as reported for Pinus oocarpa and Pinus taeda in relation to Eucalyptus urophylla, Swietenia macrophylla, Tectona grandis and Vochysia guatemalensis (Morais et al. 2005, Brand et al. 2011, Moya and Tenorio 2013, Zanuncio et al. 2014b).

Heat treatment changed the color in P. radiata and E. pellita wood in all parameters evaluated (Table 2). The behavior of heat-treated wood color of these plants differed as the temperature increased, showing the effect of species in this process. 
Table 2. Lightness $\left(\mathrm{L}^{*}\right)$, green-red coordinate $\left(\mathrm{a}^{*}\right)$, blue-yellow coordinate $\left(\mathrm{b}^{*}\right)$, color saturation (C) and tonality angle (h) of E. pellita and P. radiata wood with different extraction and heat treatment.

\begin{tabular}{|c|c|c|c|c|c|c|c|c|c|}
\hline \multirow{2}{*}{ Wood } & \multirow{2}{*}{ WHT } & \multicolumn{4}{|c|}{$170^{\circ} \mathrm{C}$} & \multicolumn{4}{|c|}{$200^{\circ} \mathrm{C}$} \\
\hline & & WE & ECW & ED & TE & WE & ECW & ED & TE \\
\hline & \multicolumn{9}{|c|}{ Lightness (L*) } \\
\hline E. pellita & $57,2 \mathrm{a}$ & $46,8 b$ & $46,9 b$ & $47,4 b$ & $47,8 \mathrm{~b}$ & $40,5 c$ & $40,6 c$ & $41,3 c$ & $41,6 \mathrm{c}$ \\
\hline \multirow[t]{2}{*}{$P$. radiata } & $74,6 a$ & $69,9 b$ & $70,5 b$ & $70,5 b$ & $69,3 \mathrm{~b}$ & $52,4 d$ & $56,1 \mathrm{c}$ & $52,6 \mathrm{~d}$ & $55,3 \mathrm{c}$ \\
\hline & \multicolumn{9}{|c|}{ Green-red coordinate $\left(\mathrm{a}^{*}\right)$} \\
\hline E. pellita & $14,0 \mathrm{a}$ & $8,2 \mathrm{c}$ & $11,4 b$ & $8,6 \mathrm{c}$ & $10,3 \mathrm{~b}$ & $3,6 \mathrm{e}$ & $5,9 \mathrm{~d}$ & $3,8 \mathrm{e}$ & $6,4 \mathrm{~d}$ \\
\hline \multirow[t]{2}{*}{$P$. radiata } & $6,7 \mathrm{~b}$ & $7,6 \mathrm{~b}$ & $7,9 \mathrm{~b}$ & $7,8 \mathrm{~b}$ & $7,5 \mathrm{~b}$ & $10,5 \mathrm{a}$ & $11,5 \mathrm{a}$ & $10,7 \mathrm{a}$ & $11,5 \mathrm{a}$ \\
\hline & \multicolumn{9}{|c|}{ Blue-yellow coordinate $\left(b^{*}\right)$} \\
\hline E. pellita & $12,9 \mathrm{a}$ & $6,6 \mathrm{c}$ & $9,3 \mathrm{~b}$ & $7,1 \mathrm{c}$ & $8,7 \mathrm{~b}$ & $4,3 \mathrm{~d}$ & $5,2 \mathrm{c}$ & $4,1 \mathrm{~d}$ & $5,3 \mathrm{c}$ \\
\hline \multirow[t]{2}{*}{ P. radiata } & $20,9 \mathrm{a}$ & $21,1 \mathrm{a}$ & $21,8 \mathrm{a}$ & $21,4 \mathrm{a}$ & $21,8 \mathrm{a}$ & $15,8 \mathrm{c}$ & $18,4 \mathrm{~b}$ & $16,4 \mathrm{c}$ & $18,8 b$ \\
\hline & \multicolumn{9}{|c|}{ Color saturation (C) } \\
\hline E. pellita & $19,1 \mathrm{a}$ & $10,5 \mathrm{c}$ & $14,8 \mathrm{~b}$ & $11,2 \mathrm{c}$ & $13,6 \mathrm{~b}$ & $5,7 \mathrm{e}$ & $8,0 \mathrm{~d}$ & $5,6 \mathrm{e}$ & $8,6 \mathrm{~d}$ \\
\hline \multirow[t]{2}{*}{ P. radiata } & $21,7 \mathrm{a}$ & $22,4 \mathrm{a}$ & $22,7 \mathrm{a}$ & $22,8 \mathrm{a}$ & $23,1 \mathrm{a}$ & $18,6 b$ & $22,7 \mathrm{a}$ & $19,5 b$ & $22,1 \mathrm{a}$ \\
\hline & \multicolumn{9}{|c|}{ Tonality angle $(\mathrm{H})$} \\
\hline E. pellita & $42,7 \mathrm{c}$ & $38,8 \mathrm{~d}$ & $39,6 \mathrm{~d}$ & $39,4 d$ & $40,5 \mathrm{~d}$ & $49,4 a$ & $46,1 b$ & $48,3 a$ & $46,2 b$ \\
\hline P. radiata & $70,2 \mathrm{a}$ & $70,1 \mathrm{a}$ & $69,5 \mathrm{a}$ & $69,7 \mathrm{a}$ & $70,3 \mathrm{a}$ & $57,1 \mathrm{c}$ & $59,5 \mathrm{~b}$ & $56,7 \mathrm{c}$ & $58,8 \mathrm{~b}$ \\
\hline
\end{tabular}

Means followed by the same letter within line do not differ by the Scott Knott test at $5 \%$ probability. WHT= Without heat treatment; $\mathrm{WE}=$ Without extraction; $\mathrm{ECW}=$ Extraction in cold water; $\mathrm{ED}=$ Extraction in dichloromethane; $\mathrm{TE}=$ Total extraction.

Heat treatment decreased the value of $\mathrm{L}^{*}$ of E. pellita and P. radiata, especially at $170^{\circ} \mathrm{C}$ and $200^{\circ} \mathrm{C}$, respectively, but with higher impact on the first specie. Softwoods are more resistant to $\mathrm{L}^{*}$ change by heat treatment (Ayadi et al. 2013, Esteves et al. 2008, 2009, 2014, Zanuncio et al. 2014a), which explains greater reduction of $P$. radiata at higher temperatures.

The removal of total extractives and extractives soluble in cold water increased the $\mathrm{L}^{*}$ of $P$. radiata treated at $200^{\circ} \mathrm{C}$. The $\mathrm{L}^{*}$ of wood without removal of extractives or after extraction with dichloromethane was lower than of those with total extraction or after extraction in cold water. The extractives soluble in dichloromethane decompose between $250^{\circ} \mathrm{C}$ and $550^{\circ} \mathrm{C}$ (Mészáros et al. 2007), which is higher than the temperature applied in this work, explaining the similar $\mathrm{L}^{*}$ value of heat treated wood with or without dichloromethane extraction.

The green-red coordinate $\left(\mathrm{a}^{*}\right)$ of $E$. pellita wood was higher than that of $P$. radiata. Heat treatment reduced the a* value of $E$. pellita and increased that of $P$. radiata, with similar values between wood species treated at $170^{\circ} \mathrm{C}$. At $200^{\circ} \mathrm{C}$, the a* values of $P$. radiata were higher than those of E. pellita, similar to that for Pinus caribeae, Pinus sylvestris, Eucalyptus grandis and Eucalyptus saligna (Kamperidou et al. 2013, Picelli et al. 2012, Cademartori et al. 2013). 
The reduction of a* values in heat-treated hardwoods is associated with phenolic extractives degradation (Pincelli et al. 2012, Moura and Brito 2011). These extractives are removed by total extraction or by extraction in cold water. Thus, the a* values in E. pellita wood with total extraction or after extraction in cold water were higher than those of heat-treated control woods. The removal of extractives soluble in cold water did not affect the $a^{*}$ value of heat-treated $P$. radiata due to its low extractive content of $1,25 \%$.

The heat treatment reduced the blue-yellow coordinate $\left(\mathrm{b}^{*}\right)$ in E. pellita and $P$. radiata wood, mainly at $170^{\circ} \mathrm{C}$ and $200^{\circ} \mathrm{C}$, respectively, the values was higher for $P$. radiata wood at all temperatures. Softwoods are more resistant to change in $b^{*}$ value compared to hardwoods (Esteves and Pereira 2009, Moura and Brito 2011, Picelli et al. 2012). Wood with total and cold water extraction showed similar $b^{*}$ value after heat treatment, but with higher values than those of timber without extraction or with dichloromethane extraction.

P. radiata wood showed higher values for color saturation (C) than E. pellita wood at all temperatures (Table 2). C value result from $\mathrm{a}^{*}$ and $\mathrm{b}^{*}$ coordinates, and the higher value of blue-yellow coordinate ( $\left.\mathrm{b}^{*}\right)$ in $P$. radiata wood made the color saturation $(\mathrm{C})$ follow $\left(\mathrm{b}^{*}\right)$ values. The removal of total extractives and extractives soluble in cold water increased the color saturation (C) of $P$. radiata wood treated at $200^{\circ} \mathrm{C}$, which is similar to the tendency for $\mathrm{b}^{*}$, and increased that of E. pellita wood treated at $170^{\circ} \mathrm{C}$ and $200^{\circ} \mathrm{C}$, for which $\mathrm{a}^{*}$ and $\mathrm{b}^{*}$ showed similar trends.

P. radiata wood showed higher tonality angle $(\mathrm{H})$ in all treatments, followed by $\mathrm{b}^{*}$ values (Table 2). Removal of extractives affected the $\mathrm{H}$ value of E. pellita and $P$. radiata wood treated at $200^{\circ} \mathrm{C}$ due to changes in the $\mathrm{a}^{*}$ and $\mathrm{b}^{*}$ coordinates at this temperature. The removal of total or soluble extractives with cold water reduced the $\mathrm{H}$ value of E. pellita, while the opposite was true for P. radiata wood.

The extractives should be considered during heat treatment for the purpose of changing wood color. Detailed knowledge about the raw materials can optimize, increase the applicability, and the economic viability of the heat treatment process in such cases. 


\section{CONCLUSIONS}

Heat treatment changes the color of wood, but with different effects on E. radiata and P. pellita. The removal of total and soluble extractives in cold water before heat treatment increased the lightness $\left(\mathrm{L}^{*}\right)$ of $P$. radiata, the green-red coordinate ( $\left.\mathrm{a}^{*}\right)$ of $E$. pellita and increased the blue-yellow coordinate $\left(\mathrm{b}^{*}\right)$, color saturation $(\mathrm{C})$ and tonality angle $(\mathrm{H})$ for both the species. The effect of extractives was higher on wood color heated treated at $200^{\circ} \mathrm{C}$, particularly after removal of total extractives and extractives soluble in cold water. The wood color after extraction in dichloromethane was similar to that without extractive removal. These compounds should be considered in heat treatment processes due to the influence of the quantity and quality of extractives on the color of heat treated wood.

\section{ACKNOWLEDGMENTS}

To "Conselho Nacional de Desenvolvimento Científico e Tecnológico (CNPq)", "Coordenação de Aperfeiçoamento de Pessoal de Nível Superior (CAPES)" and "Fundação de Amparo à Pesquisa do Estado de Minas Gerais (FAPEMIG)" for financial support. Global Edico Services edited and proof read this manuscript.

\section{REFERENCES}

ASTM. American Society for Testing and Materials. 1994. Standard test method for preparation of extractive-free wood. ASTM D1105.

ASTM. American Society for Testing and Materials. 1994. Standard test method for dicloromethane soluble in wood. ASTM D1108.

ASTM, American Society for Testing and Materials. 1994. Standard test method for water solubility of wood. ASTM D1110.

Alañón, M.E.; Pérez-Coello, M.S.; Díaz-Maroto, I.J.; Martín-Alvarez, P.J.; Vila-Lameiro, P.; Díaz-Maroto, M.C. 2011. Influence of geographical location, site and silvicultural parameters, on volatile composition of Quercus pyrenaica Willd wood used in wine aging. Forest Ecology and Management 262(2):124-130.

Ayadi, N.; Lejeune, F.; Charrier, F.; Charrier, B.; Merlin, A. 2003. Color stability of heat-treated wood during artificial weathering. European Journal of Wood and Wood Products 61(3): 221-226.

Bal, B.C.; Bektas, I. 2012. The effects of heat treatment on physical properties of juvenile wood and mature wood of Eucalyptus grandis. Bioresources 7(4): 5117- 5127.

Brand, M.A.; Muñiz, G.I.B.; Quirino, W.F.; Brito, J.O. 2011. Storage as a tool to improve wood fuel quality. Biomass and Bioenergy 35(7): 2581-2588.

Brito, J.O.; Silva, F.G.; Leão, M.M.; Almeida, G. 2008. Chemical composition changes in Eucalyptus and Pinus woods submitted to heat treatment. Bioresource Technol 99(18): 8545-8548.

Cademartori, P.H.G.; Schneid, E.; Gatto, D.A.; Beltrame, R.; Stangerlin, D.M. 2012. Modification of static bending strength properties of Eucalyptus grandis heat-treated wood. Materials Research 15(6): 922-927. 
Cademartori, P.H.G.; Schneid, E.; Gatto D.A.; Stangerlin, D.M.; Beltrame R. 2013. Thermal modification of Eucalyptus grandis wood: variation of colorimetric parameters. Maderas. Ciencia y tecnología 15(1): 57-64.

Chen, Y.; Gao, J.; Fan, Y.; Tshabalala, M.A.; Stark, N.M. 2012. Heat-induced chemical and color changes of extractive-free black locust (Robinia pseudoacacia) wood. Bioresources 7(2): 2236-2248.

Dubey, M.K.; Pang, S.; Walker, J. 2012. Changes in chemistry, color, dimensional stability and fungal resistance of Pinus radiata D. Don wood with oil heat-treatment. Holzforschung 66(1): 49-57.

Dundar, T.; Buyuksari, U.; Avci, E.; Akkiliç, H. 2012. Effect of heat treatment on the physical and mechanical properties of compression and opposite wood of black pine. Bioresources 7(4): 5009-5018.

Esteves, B.; Marques, A.V.; Domingos, I.; Pereira, H. 2013. Chemical changes of heat treated pine and eucalypt wood monitored by FTIR. Maderas. Ciencia y tecnología 15(2): 245-258.

Esteves, B.; Nunes, L.; Domingos, I.; Pereira, H. 2014. Comparison between heat treated sapwood and heartwood from Pinus pinaster. European Journal of Wood and Wood Products 72(1):53-60.

Esteves, B.; Pereira, H.M. 2009. Wood modification by heat treatment: a review. Bioresources 4(1): 370-404.

Esteves, B.; Velez-Marques, A.; Domingos, I.; Pereira, H. 2008. Heat induced colour changes of pine (Pinus pinaster) and eucalypt (Eucalyptus globulus) wood. Wood Sci Technol 42(5): 369-384.

Garcia, R.A.; Carvalho, A.M.; Latorraca, J.V.F.; Matos, J.L.M.; Santos, W.A.; Silva, R.F.M. 2012. Nondestructive evaluation of heat-treated Eucalyptus grandis Hill ex Maiden wood using stress wave method. Wood Science and Technology 46(3):41-52.

Kamperidou, V.; Barboutis, I.; Vasileiou, V. 2013. Response of colour and hygroscopic properties of Scots pine wood to thermal treatment. Journal of Forestry Research 24(3): 571-575.

Kilic, A.; Niemz, P. 2012. Extractives in some tropical woods. Eur J Wood Prod 70:79-83.

Kocaefe, D.; Poncsak, S.; Boluk, Y. 2008. Effect of thermal treatment on the chemical composition and mechanical properties of birch and aspen. BioResources 3(2): 517-537.

Korkut, S. 2012. Performance of three thermally treated tropical wood species commonly used in Turkey. Industrial Crops and Products 36(1): 355-362.

Melo, R.R.; Stangerlin, D.M.; Santana, R.R.C.; Pedrosa, T.D. 2015. Decay and termite resistance of particleboard manufactured from wood, bamboo and rice husk. Maderas. Ciencia y tecnología 17(1): $55-62$.

Mészáros, E.; Jakab, E.; Várhegyi, G. 2007. TG/MS, Py-GC/MS and THM-GC/MS study of the composition and thermal behavior of extractive components of Robinia pseudoacacia. Journal of Analytical and Applied Pyrolysis 79(1):61-70.

Moura, L.F.; Brito, J.O. 2011. Efeito da termorretificação sobre as propriedades colorimétricas das madeiras de Eucalyptus grandis e Pinus caribaea var. hondurensis. Scientia Forestalis 39(89): 69-76. 
Morais, M.C.; Pereira, H. 2012. Variation of extractives content in heartwood and sapwood of Eucalyptus globulus trees. Wood Sci Technol 46(4): 709-719.

Morais, S.A.L.; Nascimento, E.A.; Melo, D.C. 2005. Análise da madeira de Pinus oocarpa, parte I - Estudos dos constituintes moleculares e extrativos voláteis. Revista Árvore 29(3): 461-470.

Moya, R.; Tenorio, C. 2013. Fuelwood characteristics and its relation with extractives and chemical properties of ten fast-growth species in Costa Rica. Biomass and bioenergy 56(1): 14-21.

Palermo, G.P.M.; Latorraca J.V.F.; Moura, L.F.; Nolasco, A.M.; Carvalho, A.M.; Garcia, R.A. 2014. Surface roughness of heat treated Eucalyptus grandis wood. Maderas. Ciencia y tecnología 16(1): $3-12$.

Pétrissans, A.; Younsi, R.; Chaouch, M.; Gérardin, P.; Pétrissans, M. 2014. Wood thermodegradation: experimental analysis and modeling of mass loss kinetics. Maderas. Ciencia y tecnología 16(2): $133-148$.

Pincelli, A.L.P.S.M.; De Moura, L.M.; Brito, J.O. 2012. Effect of thermal rectification on colors of Eucalyptus saligna and Pinus caribaea woods. Maderas. Ciencia y tecnología 14(2): 239-248.

Ratnasingam, J.; Ioras, F. 2012. Effect of heat treatment on the machining and other properties of rubberwood. European Journal of Wood and Wood Products 70(5): 759-761.

Sun, B.; Wang, X.; Liu, J. 2013. Changes in dimensional stability and mechanical properties of Eucalyptus pellita by melamine - urea - formaldehyde resin impregnation and heat treatment. European Journal of Wood and Wood Products 71(5): 557-562.

Zanuncio, A.J.V.; Colodette, J.L.; Gomes, F.J.B.; Carneiro, A.C.O.; Vital, B.R. 2013. Composição química da madeira de eucalipto com diferentes níveis de desbaste. Ciência Florestal 23(4): 755-760.

Zanuncio, A.J.V.; Motta, J.P.; Silveira, T.A.S.; Farias, E.S.; Trugilho, P.F. 2014a. Physical and colorimetric changes in Eucalyptus grandis wood after Heat Treatment. Bioresources 9(1): 293-302.

Zanuncio, A.J.V. ; Carvalho, A.G. ; Trugilho, P.F. ; Monteiro, T.C. 2014b. Extractives and energetic properties of wood and charcoal. Revista Árvore 38(2): 369-374.

Zanuncio, A.J.V.; Nobre, J.R.C.; Motta, J.P.; Trugilho, P.F. 2014c. Componentes Químicos e colorimétricos da madeira de Eucalyptus grandis termorretificada. Revista Árvore 38(4): 563-571. 